\title{
Abnormal Regulation of Renal Vitamin D Catabolism by Dietary Phosphate in Murine X-linked Hypophosphatemic Rickets
}

\author{
Harriet S. Tenenhouse and Glenville Jones \\ Medical Research Council Genetics Group, Department of Pediatrics, McGill University, Montreal, Quebec H3H 1P3, Canada; \\ and Departments of Medicine and Biochemistry, Queen's University, Kingston, Ontario K7L 3N6, Canada
}

\begin{abstract}
Hyp mice exhibit increased renal catabolism of vitamin D metabolites by the C-24 oxidation pathway (1988. J. Clin. Invest. 81:461-465). To examine the regulatory influence of dietary phosphate on the renal vitamin D catabolic pathway in $H y p$ mice, we measured C-24 oxidation of 1,25-dihydroxyvitamin $\mathrm{D}_{3}\left(\mathbf{1 , 2 5}(\mathrm{OH})_{2} \mathrm{D}_{3}\right)$ in renal mitochondria isolated from $\mathrm{Hyp}$ mice and normal littermates fed diets containing $0.03 \%$ (lowPi), $1 \%$ (control-Pi), and 1.6\% (high-Pi) phosphate. In normal mice the low-Pi diet led to a rise in serum $1,25(\mathrm{OH})_{2} \mathrm{D}$ (22.2 \pm 1.8 to $48.1 \pm 6.8 \mathrm{pg} / \mathrm{ml}, P<0.05)$ and no change in $C-24$ oxidation products $(0.053 \pm 0.006$ to $0.066 \pm 0.008 \mathrm{pmol} / \mathrm{mg}$ protein per min) when compared with the control diet. In Hyp mice the low-Pi diet elicited a fall in serum $1,25(\mathrm{OH})_{2} \mathrm{D}$ $(21.9 \pm 1.2$ to $8.0 \pm 0.2 \mathrm{pg} / \mathrm{ml}, P<0.05)$ and a dramatic increase in $\mathrm{C}-24$ oxidation products $(0.120 \pm 0.017$ to $0.526 \pm 0.053$ $\mathrm{pmol} / \mathrm{mg}$ protein per min, $P<0.05$ ) when compared with the control diet. The high-Pi diet did not significantly alter serum levels of $1,25(\mathrm{OH})_{2} \mathrm{D}$ or $\mathrm{C}-24$ oxidation products in normal mice. Hyp mice on the high-Pi diet experienced a rise in serum $1,25(\mathrm{OH})_{2} \mathrm{D}(21.9 \pm 1.2$ to $40.4 \pm 7.3, P<0.05)$ and a fall in C-24 oxidation products $(0.120 \pm 0.017$ to $0.043 \pm 0.007 \mathrm{pmol} /$ mg protein per min, $P<0.05)$. The present results demonstrate that the defect in C-24 oxidation of $1,25(\mathrm{OH})_{2} \mathrm{D}_{3}$ in $\mathrm{Hyp}$ mice is exacerbated by phosphate depletion and corrected by phosphate supplementation. The data suggest that the disorder in vitamin D metabolism in the mutant strain is secondary to the perturbation in phosphate homeostasis. (J. Clin. Invest. 1990. 85:1450-1455.) Hyp mouse $\bullet$ 1,25-dihydroxyvitamin $D_{3}$ - 1,24,25-trihydroxyvitamin $D_{3} \cdot C-24$ oxidation $•$ 25-hydroxyvitamin $D_{3}$-24-hydroxylase
\end{abstract}

\section{Introduction}

The murine hypophosphatemic $(H y p)^{1}$ mutation, a homologue of X-linked hypophosphatemia in man, is a Mendelian

A preliminary report of this work was presented at the American Society of Bone and Mineral Research in Montreal, Quebec, Canada, September 1989.

Address correspondence to Dr. Harriet S. Tenenhouse, MRC Genetics Group, Montreal Children's Hospital, 2300 Tupper Street, Montreal, Quebec, Canada H3H 1 P3.

Received for publication 5 July 1989 and in revised form 3 January 1990.

1. Abbreviations used in this paper: 24-hydroxylase, 25-hydroxyvitamin $\mathrm{D}_{3}$-24-hydroxylase; $H y p$, hypophosphatemic; $1,25(\mathrm{OH})_{2} \mathrm{D}_{3}$,

J. Clin. Invest.

(C) The American Society for Clinical Investigation, Inc.

0021-9738/90/05/1450/06\$2.00

Volume 85, May 1990, 1450-1455 disorder of phosphate homeostasis characterized by hypophosphatemia, rickets, and a specific impairment in renal brush border membrane phosphate transport $(1,2)$. The demonstration of normal plasma concentrations of 1,25-dihydroxyvitamin $\mathrm{D}\left(1,25(\mathrm{OH})_{2} \mathrm{D}\right)$ in adult $H y p$ mice (3) and in patients with X-linked hypophosphatemia (4), in the face of significant hypophosphatemia, suggested that the X-linked mutation also perturbs the regulation of renal vitamin $\mathrm{D}$ metabolism. Indeed, Hyp mice exhibit a blunted response to activators of renal $1,25(\mathrm{OH})_{2} \mathrm{D}_{3}$ synthesis when compared with normal littermates $(3,5-10)$, and also demonstrate increased renal catabolism of $1,25(\mathrm{OH})_{2} \mathrm{D}_{3}(11)$ and other vitamin $\mathrm{D}$ metabolites (12). Studies in our laboratories have demonstrated that accelerated renal degradation of vitamin D metabolites in the mutant strain can be attributed to increased renal 25-hydroxyvitamin $\mathrm{D}_{3}$-24-hydroxylase (24-hydroxylase) activity, the first enzyme in the C-24 oxidation pathway, which converts the vitamin $\mathrm{D}$ hormone to 1,24,25-trihydroxyvitamin $D_{3}$, a metabolite with reduced biological activity (11).

The renal 25-hydroxyvitamin $D_{3}$-1-hydroxylase response to dietary phosphate intake is physiologically inappropriate in Hyp mice when compared with normal littermates $(9,10)$. Whereas phosphate restriction stimulates renal $1,25(\mathrm{OH})_{2} \mathrm{D}_{3}$ production in normal mice, the low-phosphate diet elicited an inhibition of vitamin $D$ hormone synthesis in the mutant strain $(9,10)$. In addition, it was also reported that whereas phosphate supplementation did not significantly alter $1,25(\mathrm{OH})_{2} \mathrm{D}_{3}$ production in normal mice, high-phosphate diets led to a marked increase in renal $1,25(\mathrm{OH})_{2} \mathrm{D}_{3}$ synthesis in the mutant strain (10).

It is well established that both the synthetic (1-hydroxylase, 25-hydroxyvitamin $D_{3}$-1-hydroxylase) and the catabolic (24hydroxylase) enzymes for $1,25(\mathrm{OH})_{2} \mathrm{D}_{3}$ are expressed in mammalian kidney (13). However, with the exception of those studies that examined renal $1,25(\mathrm{OH})_{2} \mathrm{D}_{3}$ synthesis in vitamin $\mathrm{D}$ and calcium-deprived $H y p$ mice, where renal 24-hydroxylase activity was completely suppressed (5-7), and where the production of 1,24,25-trihydroxyvitamin $D_{3}$ was monitored and not detected (14), 1,25(OH) ${ }_{2} \mathrm{D}_{3}$ synthesis in the mutant strain has been quantitated in renal preparations capable of both the synthetic and catabolic pathways (8-10). Accordingly, it is difficult to establish whether the net decrease in $1,25(\mathrm{OH})_{2} \mathrm{D}_{3}$ synthesis observed in phosphate-deprived $H y p$ mice $(9,10)$ is due to decreased synthesis or increased catabolism of the hormone. Similarly, the net increase in $1,25(\mathrm{OH})_{2} \mathrm{D}_{3}$ synthesis in the phosphate-supplemented Hyp mice (10) may be ascribed to increased synthesis or decreased catabolism. This problem may be further complicated if both the vitamin $D$ hormone synthetic and catabolic pathways are differentially regulated in

1,25-dihydroxyvitamin $\mathrm{D}_{3} ; 25(\mathrm{OH}) \mathrm{D}_{3}, 25$-hydroxyvitamin $\mathrm{D}_{3}$; $24,25(\mathrm{OH})_{2} \mathrm{D}_{3}, 24,25$-dihydroxyvitamin $\mathrm{D}_{3}$. 
each genotype, i.e., if the $H y p$ mutation perturbs not only the response of $H y p$ mice to regulators of vitamin D hormone synthesis $(6,7)$ but also to factors that influence $1,25(\mathrm{OH})_{2} \mathrm{D}_{3}$ catabolism.

The present study was undertaken to investigate the effect of the Hyp mutation on the regulation of the renal vitamin D catabolic pathway by dietary phosphate. We examined C-24 oxidation of $1,25(\mathrm{OH})_{2} \mathrm{D}_{3}$ in renal mitochondria isolated from Hyp mice and normal littermates fed diets containing $0.03 \%$ (low-Pi), $1 \%$ (control-Pi), and $1.6 \%$ (high-Pi) phosphate for $4 \mathrm{~d}$. We report that, whereas dietary phosphate does not appear to significantly influence the vitamin D catabolic pathway in normal mice, phosphate deprivation dramatically increases and phosphate supplementation decreases renal C-24 oxidation of $1,25(\mathrm{OH})_{2} \mathrm{D}_{3}$ in the mutant strain. Furthermore, after phosphate supplementation, genotype differences in renal $1,25(\mathrm{OH})_{2} \mathrm{D}_{3}$ catabolism are no longer apparent.

\section{Methods}

Mice. Normal $(+/ \mathrm{Y})$ and hemizygous mutant male $(\mathrm{Hyp} / \mathrm{Y})$ mice were bred and raised at the Montreal Children's Hospital (Montreal, Quebec, Canada). The initial breeding pairs $(\mathrm{C} 57 \mathrm{Bl} / 6 \mathrm{~J}$ males and $\mathrm{Hyp} /+$ females) were obtained from Jackson Laboratories (Bar Harbor, ME). The mice were raised on Wayne Lab Blox (Allied Mills Inc., Chicago, IL) containing $1.2 \%$ calcium, $0.99 \%$ phosphorus, and 4.41 IU vitamin $\mathrm{D}_{3} / \mathrm{g}$. To examine the effect of dietary phosphate on renal C-24 oxidation of vitamin D metabolites, 4-5-mo-old $+/ \mathrm{Y}$ and $\mathrm{Hyp} / \mathrm{Y}$ littermates were fed test diets containing $0.03 \%$ (low-Pi), $1 \%$ (control-Pi), and $1.65 \%$ (high-Pi) phosphate (test diets 86128,86129 , and 88345 , respectively; Teklad, Madison, WI) for $4 \mathrm{~d}$ before killing. The diets contained $1 \%$ calcium and $2.2 \mathrm{IU}$ vitamin $\mathrm{D}_{3} / \mathrm{g}$ and were identical in all respects except for phosphate content.

Measurement of serum and urine parameters. Serum and urine phosphate and calcium were assayed as described previously (7). The urine creatinine concentration was assayed with a Creatinine II Rapid Stat Kit (Sherwood Medical Industries, Inc., St. Louis, MO). The serum concentration of $1,25(\mathrm{OH})_{2} \mathrm{D}$ was measured using a calf thymus radioreceptor assay kit (Incstar, Stillwater, MN). The urine concentration of cAMP was determined by competitive binding assay using a commercial kit (Amersham Canada Ltd., Oakville, Ontario, Canada).

Renal metabolism of vitamin $D_{3}$ metabolites. Mitochondria were prepared from renal cortex of individual mice according to the method of Vieth and Fraser (15). In our standard assay, $1 \mathrm{ml}$ of oxygenated mitochondria containing $\sim 2 \mathrm{mg}$ mitochondrial protein in $125 \mathrm{mM}$ $\mathrm{KCl}, 20 \mathrm{mM}$ Hepes, $10 \mathrm{mM}$ malic acid, $2 \mathrm{mM} \mathrm{MgSO}_{4}, 1 \mathrm{mM}$ dithio-

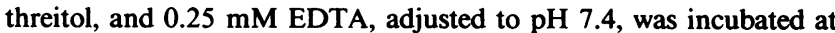
$25^{\circ} \mathrm{C}$ with either $50 \mathrm{nM}\left[{ }^{3} \mathrm{H}\right] 1,25(\mathrm{OH})_{2} \mathrm{D}_{3}(\sim 2,000 \mathrm{cpm} / \mathrm{pmol})$ or 500 $\mathrm{nM}\left[{ }^{3} \mathrm{H}\right] 25(\mathrm{OH}) \mathrm{D}_{3}(\sim 200 \mathrm{cpm} / \mathrm{pmol})$ for 5-15 min as described previously (11). Reaction mixtures in which boiled mitochondria were incubated with $\left[{ }^{3} \mathrm{H}\right]$ vitamin $\mathrm{D}_{3}$ substrates served as background in the quantitation of product formation. Enzyme activity was estimated under initial rate conditions by the sum of C-24 oxidation products for $1,25(\mathrm{OH})_{2} \mathrm{D}_{3}$, defined as 1,24,25-trihydroxyvitamin $\mathrm{D}_{3}, 24$-oxo-1,25dihydroxyvitamin $D_{3}$, and 24-oxo-1,23,25-trihydroxyvitamin $D_{3}$, and for $25(\mathrm{OH}) \mathrm{D}_{3}$, defined as 24,25 -dihydroxyvitamin $D_{3}$ $\left(24,25(\mathrm{OH})_{2} \mathrm{D}_{3}\right), 24-0 x 0-25$-hydroxyvitamin $\mathrm{D}_{3}$, and 24-oxo-23,25dihydroxyvitamin $D_{3}$. Under these conditions of high substrate concentrations and short incubation times, no appreciable amounts of other lipid-soluble C-24 oxidation products (e.g., tetranor-1,23$(\mathrm{OH})_{2} \mathrm{D}_{3}$ ) or water-soluble $\mathrm{C}-24$ oxidation products (e.g., calcitroic acid) were formed. The reactions were stopped by the addition of 3.75 $\mathrm{ml}$ chloroform/methanol (1:2) and samples stored at $-20^{\circ} \mathrm{C}$ under $\mathrm{N}_{2}$ until extraction and analysis. $\left[{ }^{3} \mathrm{H}\right]$ Vitamin $\mathrm{D}_{3}$ metabolites were purchased from Amersham, Canada Ltd., and crystalline vitamin $D_{3}$ me- tabolites were gifts from Hoffmann-LaRoche Ltd., Etobicoke, Ontario, Canada.

Extraction and assay of vitamin $D_{3}$ metabolites. Extraction of reaction mixtures was performed twice as described by Bligh and Dyer (16). Approximately $90 \%$ of ${ }^{3} \mathrm{H}$-label was recovered from incubations with either intact or boiled mitochondria (where no significant conversion of substrate is apparent). Chromatographic separation of $1,25(\mathrm{OH})_{2} \mathrm{D}_{3}, 1,24,25$-trihydroxyvitamin $\mathrm{D}_{3}$, 24-oxo-1,25-dihydroxyvitamin $D_{3}$, and 24-oxo-1,23,25-trihydroxyvitamin $D_{3}$ was achieved on Zorbax SIL ( $6.2 \mathrm{~mm} \times 25 \mathrm{~cm}$ ) with hexane/isopropanol/methanol (88:10:2) (11). Rechromatography of C-24 oxidation peaks from Zorbax SIL on Zorbax CN (4.6 $\mathrm{mm} \times 25 \mathrm{~cm})$ with hexane/isopropanol/ methanol $(91: 7: 2)(17,18)$ confirmed that the 1,24,25-trihydroxyvitamin $D_{3}$ and 24-oxo-1,25-dihydroxyvitamin $D_{3}$ peaks were pure. The 24-oxo-1,23,25-trihydroxyvitamin $\mathrm{D}_{3}$ peak contained $\sim 20 \%$ 1,23,25-trihydroxyvitamin $D_{3}$, a percentage which did not change with dietary phosphate. Under our incubation conditions, 24-oxo-1,23,25trihydroxyvitamin $\mathrm{D}_{3}$ comprised $\sim 20 \%$ of total product formed from $1,25(\mathrm{OH})_{2} \mathrm{D}_{3}(11)$. Thus, $\mathrm{C}-23$ oxidation, which is defined as the production of $1,23,25$-trihydroxyvitamin $D_{3}$, accounted for $<4 \%$ of total catabolic activity in these studies. Chromatographic separation of $25(\mathrm{OH}) \mathrm{D}_{3}, 24,25(\mathrm{OH})_{2} \mathrm{D}_{3}, 24-0 x 0-25$-hydroxyvitamin $\mathrm{D}_{3}$, and 24oxo-23,25-dihydroxyvitamin $\mathrm{D}_{3}$ was achieved on Zorbax $\mathrm{CN}(4.6 \mathrm{~mm}$ $\times 25 \mathrm{~cm})$ with hexane/isopropanol/methanol (94:5:1) as described previously $(16,17)$. The identity of products was confirmed by cochromatography with standards authenticated by mass spectrometry.

Statistical methods. Data were analyzed using SAS software by two-way analysis of variance $(2 \times 3$ factorial analysis). For variables that did not show a significant diet-genotype interaction (serum calcium, urine phosphate/creatinine, urine calcium/creatinine, urine cAMP/creatinine), the effect of diet within each genotype was analyzed by Tukey's multiple comparison approach. For variables that showed a significant diet-genotype interaction (C-24 oxidation products of $1,25(\mathrm{OH})_{2} \mathrm{D}_{3}$ and $25(\mathrm{OH}) \mathrm{D}_{3}$, serum $1,25(\mathrm{OH})_{2} \mathrm{D}$, serum phosphate), the six groups were compared by Tukey's multiple comparison approach. A simple $t$ test was used to compare genotypes on the control diet; this approach was appropriate because the hypothesis of genotype difference on the control diet can be considered an apriori hypothesis on the basis of past studies in which significant genotype differences were reported $(5,11,12,14)$.

\section{Results}

Effect of phosphate deprivation. The effect of dietary phosphate deprivation on serum and urine parameters in $+/ \mathrm{Y}$ and $H y p$ mice is shown in Table I. The low-Pi diet elicited a fall in serum phosphate, a drop in the urine phosphate/creatinine ratio, a small rise in serum calcium, and a marked increase in the urine calcium/creatinine ratio in both genotypes. In addition, both genotypes experienced a decrease in urinary cAMP excretion, relative to creatinine, in response to phosphate deprivation. The urine creatinine concentration $(3.76 \pm 0.02$ $\mathrm{mM}$, mean $\pm \mathrm{SEM}, n=47$ ) was not influenced by either dietary phosphate or the Hyp mutation.

The effect of dietary phosphate deprivation on renal mitochondrial catabolism of $1,25(\mathrm{OH})_{2} \mathrm{D}_{3}$ in normal and $\mathrm{Hyp}$ mice is shown in Fig. 1. In normal mice, the low-Pi diet had no effect on the rate of appearance of $\mathrm{C}-24$ oxidation products $(0.053 \pm 0.006$ vs. $0.066 \pm 0.008 \mathrm{pmol} / \mathrm{mg}$ protein per min for control-Pi and low-Pi diets, respectively). In contrast, $H y p$ mice responded to dietary phosphate restriction with a marked increase in $\mathrm{C}-24$ oxidation of $1,25(\mathrm{OH})_{2} \mathrm{D}_{3}(0.120 \pm 0.017$ vs. $0.526 \pm 0.053 \mathrm{pmol} / \mathrm{mg}$ protein per min for control-Pi and low-Pi diets, respectively). These results clearly demonstrate that the genotype difference in $1,25(\mathrm{OH})_{2} \mathrm{D}_{3}$ catabolism is 
Table I. Effect of Dietary Phosphate on Serum and Urine Parameters in $+/ Y$ and Hyp/Y Mice

\begin{tabular}{|c|c|c|c|}
\hline & Low-Pi diet & Control diet & High-Pi diet \\
\hline \multicolumn{4}{|c|}{ Serum Pi $(m g \%)$} \\
\hline$+/ Y$ & $3.68 \pm 0.12^{*}$ & $7.76 \pm 0.25$ & $8.83 \pm 0.35^{*}$ \\
\hline$H y p / \mathrm{Y}$ & $2.90 \pm 0.31^{* \neq}$ & $4.74 \pm 0.22^{\ddagger}$ & $5.77 \pm 0.21^{* \neq}$ \\
\hline \multicolumn{4}{|c|}{ Serum Ca $(m g \%)$} \\
\hline$+/ Y$ & $9.84 \pm 0.24^{*}$ & $8.64 \pm 0.16$ & $8.60 \pm 0.28$ \\
\hline$H y p / \mathrm{Y}$ & $9.04 \pm 0.16^{*}$ & $8.16 \pm 0.28$ & $8.28 \pm 0.16$ \\
\hline \multicolumn{4}{|c|}{$\begin{array}{l}\text { Urine } \mathrm{Pi} / \text { creatinine } \\
\qquad(m g / m g)\end{array}$} \\
\hline$+/ \mathrm{Y}$ & $0.02 \pm 0.00^{*}$ & $7.54 \pm 0.09$ & $21.21 \pm 1.56^{*}$ \\
\hline$H y p / Y$ & $0.03 \pm 0.00^{*}$ & $8.06 \pm 0.62$ & $19.96 \pm 2.78^{*}$ \\
\hline \multicolumn{4}{|c|}{$\begin{array}{l}\text { Urine } \mathrm{Ca} / \text { creatinine } \\
\qquad(m g / m g)\end{array}$} \\
\hline$+/ \mathrm{Y}$ & $2.26 \pm 0.13^{*}$ & $0.06 \pm 0.02$ & $0.06 \pm 0.02$ \\
\hline Hyp/Y & $2.37 \pm 0.18^{*}$ & $0.08 \pm 0.02$ & $0.06 \pm 0.02$ \\
\hline \multicolumn{4}{|c|}{$\begin{array}{l}\text { Urine cAMP/creatinine } \\
\qquad(\mathrm{nmol} / \mathrm{mg})\end{array}$} \\
\hline$+/ \mathrm{Y}$ & $15.0 \pm 1.1^{*}$ & $27.5 \pm 2.3$ & $52.6 \pm 5.9^{*}$ \\
\hline$H y p / \mathrm{Y}$ & $15.1 \pm 1.1^{*}$ & $38.4 \pm 4.8$ & $52.4 \pm 4.8^{*}$ \\
\hline
\end{tabular}

Values are means \pm SEM derived from five to eight mice in each group. Data were analyzed as described in Methods. A significant diet-genotype interaction was observed for serum $\mathrm{Pi}(\mathrm{F}[2,3]=14.63$, $P=0.0001$ ).

* Effect of diet $P<0.05$; *effect of genotype $P<0.05$.

more pronounced on the low-Pi diet than on the control diet (Fig. 1).

The effect of phosphate restriction on the renal catabolism of 25-hydroxyvitamin $\mathrm{D}_{3}\left(25(\mathrm{OH}) \mathrm{D}_{3}\right)$ in $+/ \mathrm{Y}$ and Hyp mice is shown in Fig. 2, and is similar to that seen for $1,25(\mathrm{OH})_{2} \mathrm{D}_{3}$ (Fig. 1), i.e., the low-Pi diet stimulates the catabolic pathway in mutant mice $(0.594 \pm 0.109$ vs. $1.993 \pm 0.451 \mathrm{pmol} / \mathrm{mg}$ protein per min for control-Pi and low-Pi diets, respectively), but has no effect in normal littermates $(0.305 \pm 0.034$ vs. $0.353 \pm 0.060$ $\mathrm{pmol} / \mathrm{mg}$ protein per min for control-Pi and low-Pi diets, respectively). Again, the genotype difference in the vitamin D catabolic pathway is significantly greater in mice fed the low-Pi diet.

Fig. 3 depicts the effect of phosphate deprivation on the serum concentration of $1,25(\mathrm{OH})_{2} \mathrm{D}$. In agreement with pre-

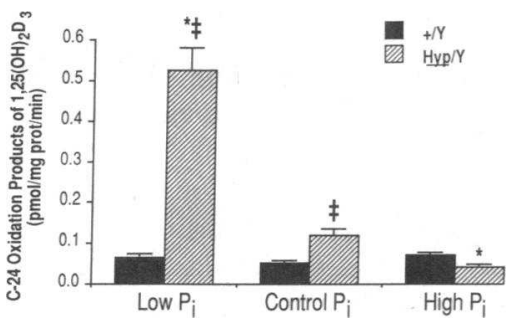

Figure 1. Effect of dietary phosphate on rate of formation of C-24 oxidation products of $1,25(\mathrm{OH})_{2} \mathrm{D}_{3}$ by $+/ \mathrm{Y}$ and $H y p / Y$ mice. Renal mitochondria from individual normal and mutant mice were incubated with $50 \mathrm{nM}$

$\left[{ }^{3} \mathrm{H}\right] 1,25(\mathrm{OH})_{2} \mathrm{D}_{3}$ for $7.5 \mathrm{~min}$ at $25^{\circ} \mathrm{C}$. Extraction and HPLC of vitamin $D_{3}$ metabolites were performed as described in Methods. Each bar depicts mean \pm SEM and is based on values derived from five to eight mice in each group. Data were analyzed as described in Methods. A significant diet-genotype interaction was observed $(\mathrm{F}[2,35]=60.00, P=0.001)$. ${ }^{*}$ Effect of diet, $P<0.05$; ${ }^{*}$ effect of genotype, $P<0.05$.

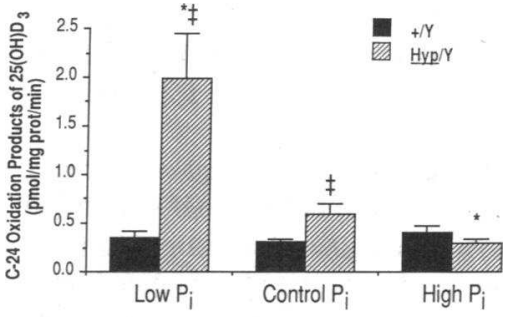

Figure 2. Effect of dietary phosphate on rate of formation of C-24 oxidation products of $25(\mathrm{OH}) \mathrm{D}_{3}$ by $+/ \mathrm{Y}$ and Hyp/Y mice. Renal mitochondria from individual normal and mutant mice were incubated with $500 \mathrm{nM}$

$\left[{ }^{3} \mathrm{H}\right] 25(\mathrm{OH}) \mathrm{D}_{3}$ for $15 \mathrm{~min}$ at $25^{\circ} \mathrm{C}$. Extraction and HPLC of vitamin $\mathrm{D}_{3}$ metabolites were performed as described in Methods. Each bar depicts mean \pm SEM and is based on values derived from four mice in each group. Data were analyzed as described in Methods. A significant diet-genotype interaction was observed $(\mathrm{F}[2,18]=11.18, P$ $=0.0007) .{ }^{*}$ Effect of diet, $P<0.05$ or less; ${ }^{\ddagger}$ effect of genotype, $P$ $<0.05$.

vious reports $(3,14)$, genotype differences were not apparent in mice fed the control diet $(22.2 \pm 1.8$ vs. $21.9 \pm 1.2 \mathrm{pg} / \mathrm{ml}$ in $+/ Y$ and $H y p / Y$, respectively). However, whereas normal mice respond to phosphate restriction with a 2.2-fold increase in the circulating concentration of $1,25(\mathrm{OH})_{2} \mathrm{D}(48.1 \pm 6.8 \mathrm{pg} / \mathrm{ml})$, Hyp mice fed the low-Pi diet exhibit a significant fall in the serum level of vitamin D hormone $(8.0 \pm 0.2 \mathrm{pg} / \mathrm{ml})$.

Effect of phosphate supplementation. Table I summarizes the effects of phosphate supplementation on serum and urine parameters in normal and $H y p$ mice. In both genotypes, the high-Pi diet led to a significant rise in serum phosphate and to an increase in the urinary excretion of phosphate and cAMP relative to creatinine. Neither genotype experienced a change in serum calcium or urine calcium/creatinine excretion on the high-Pi diet (Table I).

The high-Pi diet had no significant effect on the catabolism of $1,25(\mathrm{OH})_{2} \mathrm{D}_{3}(0.053 \pm 0.006$ vs. $0.070 \pm 0.009 \mathrm{pmol} / \mathrm{mg}$ protein per min in control-Pi and high-Pi diets, respectively, Fig. 1) or $25(\mathrm{OH}) \mathrm{D}_{3}(0.305 \pm 0.034$ vs. $0.408 \pm 0.060 \mathrm{pmol} / \mathrm{mg}$ protein per min in control-Pi and high-Pi diets, respectively, Fig. 2 ) in normal mice. In contrast, renal C-24 oxidation of both vitamin D metabolites (Figs. 1 and 2) was significantly reduced by phosphate supplementation of mutant mice (for $1,25(\mathrm{OH})_{2} \mathrm{D}_{3}, 0.120 \pm 0.017$ vs. $0.043 \pm 0.007 \mathrm{pmol} / \mathrm{mg}$ protein per min in control-Pi and high-Pi diets, respectively; and for $25(\mathrm{OH}) \mathrm{D}_{3}, 0.594 \pm 0.109$ vs. $0.293 \pm 0.050 \mathrm{pmol} / \mathrm{mg}$ protein per min in control-Pi and high-Pi diets, respectively). Finally, whereas the high-Pi diet did not affect the serum concentration

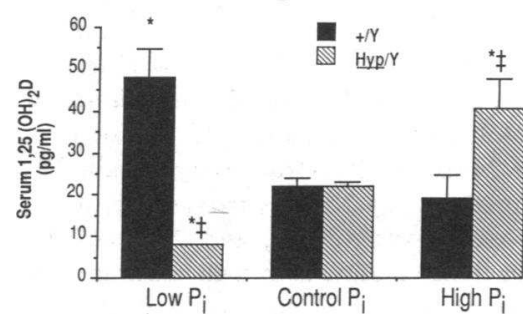

Figure 3. Effect of dietary phosphate on the serum concentration of $1,25(\mathrm{OH})_{2} \mathrm{D}$ in $+/ \mathrm{Y}$ and $H y p / Y$ mice. The concentration of $1,25(\mathrm{OH})_{2} \mathrm{D}$ was measured using a calf thymus radioreceptor assay kit. Each bar depicts mean \pm SEM and is based on at least three pooled serum samples, each of which was derived from five to eight mice. Data were analyzed as described in Methods. A significant diet-genotype interaction was observed $(\mathrm{F}[2,17]=35.69, P=0.0001)$. ${ }^{*}$ Effect of diet, $P$ $<0.05$; ₹effect of genotype, $P<0.05$. 
of $1,25(\mathrm{OH})_{2} \mathrm{D}$ in normal mice $(22.2 \pm 1.8$ vs. $19.0 \pm 5.7 \mathrm{pg} / \mathrm{ml}$ in control-Pi and high-Pi diets, respectively), phosphate-supplemented mutant mice exhibited an increase in the circulating levels of the vitamin D hormone $(21.9 \pm 1.2$ vs. $40.4 \pm 7.3$ $\mathrm{pg} / \mathrm{ml}$ in control-Pi and high-Pi diets, respectively).

Fig. $4 \mathrm{~A}$ depicts the relationship between the steady-state serum concentration of $1,25(\mathrm{OH})_{2} \mathrm{D}$ and the serum phosphate concentration in normal and $H y p$ mice. It is clear that the serum $1,25(\mathrm{OH})_{2} \mathrm{D}$ response to changes in serum phosphate is opposite in direction in $H y p$ mice when compared with normal littermates. In Hyp mice the hormone level increases with a rise in serum phosphate, whereas in normal littermates the hormone level decreases with a rise in serum phosphate. Fig. 4 $B$ depicts the relationship between renal C-24 oxidation of $1,25(\mathrm{OH})_{2} \mathrm{D}_{3}$ and the serum phosphate concentration in normal and Hyp mice. At serum phosphate concentrations $<5$ $\mathrm{mg} \%$, the renal catabolism of vitamin $\mathrm{D}$ hormone is higher in Hyp mice than in normal littermates.

\section{Discussion}

The present study demonstrates for the first time that the renal catabolism of the vitamin $\mathrm{D}$ hormone, $1,25(\mathrm{OH})_{2} \mathrm{D}_{3}$, as measured by the production of $\mathrm{C}-24$ oxidation products, is markedly stimulated by phosphate deprivation and inhibited by phosphate supplementation in X-linked Hyp mice. In contrast to the mutant strain, $1,25(\mathrm{OH})_{2} \mathrm{D}_{3}$ catabolism does not appear to be modulated by dietary phosphate in normal mice. Our data also demonstrate that dietary phosphate deprivation lowers the serum concentration of $1,25(\mathrm{OH})_{2} \mathrm{D}$ in $\mathrm{Hyp}$ mice, while dietary phosphate supplementation increases the circulating hormone level. In normal mice, dietary phosphate supplementation has no effect on the circulating levels of $1,25(\mathrm{OH})_{2} \mathrm{D}$, whereas phosphate deprivation is accompanied by an increase in serum $1,25(\mathrm{OH})_{2} \mathrm{D}$ as reported previously (3).

Our data suggest that the failure of $H y p$ mice to respond to dietary phosphate deprivation with increased serum levels of $1,25(\mathrm{OH})_{2} \mathrm{D}$ may be ascribed to the substantial increase in renal vitamin $\mathrm{D}$ hormone catabolism as well as to the reported decrease in $1,25(\mathrm{OH})_{2} \mathrm{D}_{3}$ synthesis $(9,10)$ observed in the mu-
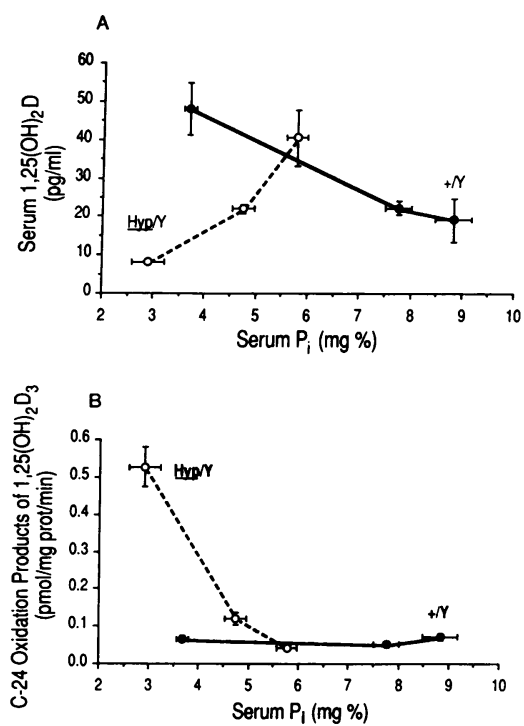

Figure 4. A, Relationship between steady serum concentration of $1,25(\mathrm{OH})_{2} \mathrm{D}$ and serum phosphate concentration in $+/ Y(\bullet)$ and $H y p / Y(0)$ mice. B, Relationship between the rate of formation of C-24 oxidation products of $1,25(\mathrm{OH})_{2} \mathrm{D}_{3}$ and serum phosphate concentration in $+/ Y$ (•) and $H y p / \mathrm{Y}(\mathrm{O})$ mice. Data are taken from Table I and Figs. 1 and 3. tant strain under these conditions. Conversely, the significant rise in serum $1,25(\mathrm{OH})_{2} \mathrm{D}$ elicited by phosphate supplementation of Hyp mice may be attributed to the decrease in renal vitamin $\mathrm{D}$ hormone degradation as well as to the reported increase in $1,25(\mathrm{OH})_{2} \mathrm{D}_{3}$ synthesis (10) that occurs after feeding high-Pi diets to the mutant strain. Our results also demonstrate that the renal vitamin $\mathrm{D}$ catabolic pathway is a more important determinant of the steady-state serum concentration of $1,25(\mathrm{OH})_{2} \mathrm{D}$ in the mutant mice than in normal littermates where the synthetic pathway alone appears to play a regulatory role.

The present study emphasizes the need to consider $1,25(\mathrm{OH})_{2} \mathrm{D}_{3}$ breakdown in investigations designed to assay $1,25(\mathrm{OH})_{2} \mathrm{D}_{3}$ synthesis. In these $25(\mathrm{OH}) \mathrm{D}_{3}-1$-hydroxylase assay systems, small amounts of $1,25(\mathrm{OH})_{2} \mathrm{D}_{3}$ synthesized may be susceptible to further metabolism by $\mathrm{C}-24$ oxidation enzymes, and therefore rendered unmeasurable by the $1,25(\mathrm{OH})_{2} \mathrm{D}_{3}$ detection techniques. Furthermore, physiological factors that alter the rate of $1,25(\mathrm{OH})_{2} \mathrm{D}_{3}$ catabolism might lead to alterations in the stability of the $1,25(\mathrm{OH})_{2} \mathrm{D}_{3}$ produced. One way to overcome this problem may be to use high concentrations of the $25(\mathrm{OH}) \mathrm{D}_{3}$ substrate to saturate the $\mathrm{C}-24$ oxidation enzymes. Previous studies that demonstrated reduced $1,25(\mathrm{OH})_{2} \mathrm{D}_{3}$ synthesis in phosphate-deprived $H y p$ mice $(9,10)$ and increased $1,25(\mathrm{OH})_{2} \mathrm{D}_{3}$ synthesis in phosphatesupplemented mutants (10) used such high $25(\mathrm{OH}) \mathrm{D}_{3}$ concentrations. However, until $1,25(\mathrm{OH})_{2} \mathrm{D}_{3}$ catabolism is examined directly under the conditions used to assay $1,25(\mathrm{OH})_{2} \mathrm{D}_{3}$ synthesis, it is not clear whether the reported changes in $1,25(\mathrm{OH})_{2} \mathrm{D}_{3}$ synthesis in $H y p$ mice $(9,10)$ can be ascribed to alterations in vitamin $\mathrm{D}$ hormone synthesis, catabolism, or both.

Dietary phosphate and/or phosphate availability have long been recognized as important determinants in the regulation of $1,25(\mathrm{OH})_{2} \mathrm{D}_{3}$ synthesis by mammalian and avian kidney (19-21). However, the precise role of phosphate in the regulation of the vitamin D catabolic pathway is not as clear. In vivo studies demonstrated that the production of $24,25(\mathrm{OH})_{2} \mathrm{D}_{3}$ from intravenously injected $\left[{ }^{3} \mathrm{H}\right] 25(\mathrm{OH}) \mathrm{D}_{3}$ was reciprocally related to the production of $1,25(\mathrm{OH})_{2} \mathrm{D}_{3}$ over a wide range of serum phosphate concentrations, achieved by modulating dietary phosphate intake in thyroparathyroidectomized rats (19). Since 24-hydroxylase is the first enzyme in the C-24 oxidation pathway, these results suggested, albeit indirectly, that the catabolic pathway is inhibited by phosphate deprivation and stimulated by phosphate supplementation. Studies in isolated renal mitochondria derived from phosphate-deprived normal mice and phosphate-supplemented $H y p$ mice led to similar conclusions; namely, that phosphate restriction inhibited 24-hydroxylase activity in normal mice and phosphate supplementation stimulated $24,25(\mathrm{OH})_{2} \mathrm{D}_{3}$ synthesis in $H y p$ mice (22). However, these data are not compatible with those of the present study, in which we clearly demonstrate that in normal mice dietary phosphate intake does not have a significant effect on the degradation of vitamin $D_{3}$ metabolites, whereas in $H y p$ mice the catabolic pathway is stimulated by phosphate restriction and inhibited by phosphate supplementation. Our results in normal mice are consistent with those of Portale et al. (23), who demonstrated that dietary phosphateinduced changes in the serum concentration of $1,25(\mathrm{OH})_{2} \mathrm{D}$ in normal men could be accounted for entirely by changes in the production rate of the hormone and not by changes in the 
metabolic clearance rate. To our knowledge, the metabolic clearance rate of $1,25(\mathrm{OH})_{2} \mathrm{D}$ and its modulation by dietary phosphate have not been examined in patients with $\mathrm{X}$-linked hypophosphatemia. However, a study with the murine homologue showed that plasma clearance of high doses of exogenous $1,25(\mathrm{OH})_{2} \mathrm{D}_{3}$ is more rapid in Hyp mice than in normal littermates (24), in agreement with our present and previous data (11).

The effect of the Hyp mutation on the vitamin D catabolic pathway in target tissues other than the kidney is of specific interest. In this regard, we have been unable to detect C-24 oxidation of $1,25(\mathrm{OH})_{2} \mathrm{D}$ in duodenal homogenates derived from either normal or mutant mice (25). In addition, we failed to demonstrate genotype differences in $1,25(\mathrm{OH})_{2} \mathrm{D}_{3}$-inducible intestinal 24-hydroxylase activity (25). We also found that, in contrast to the kidney, duodena from phosphate-deprived $H y p$ mice failed to exhibit an increase in 24-hydroxylase activity (Tomon, M., and H. S. Tenenhouse, unpublished results). Similarly, Delvin et al. (26) recently reported no difference in $1,25(\mathrm{OH})_{2} \mathrm{D}_{3}$-inducible 24 -hydroxylase activity in primary osteoblastic cultures from normal and $H y p$ mice. Taken together, these results suggest that the disorder in vitamin D catabolism, like the impairment in phosphate transport (27), is only expressed in the kidney of the mutant strain.

In this study we demonstrate that the renal defect in $1,25(\mathrm{OH})_{2} \mathrm{D}_{3}$ catabolism in $H y p$ mice can be corrected by phosphate supplementation. These results suggest that the disorder in the regulation of renal vitamin D metabolism in the mutant strain is secondary to the perturbation in phosphate homeostasis. Although we have not directly investigated the effect of phosphate supplementation on the renal brush border membrane phosphate transport defect, it is clear from our in vivo data that the high-Pi diet did not normalize the fractional excretion index for phosphate in $H y p$ mice when compared with $+/ Y$ littermates (urine phosphate/urine creatinine/serum phosphate $=2.40$ and 3.46 for phosphate-supplemented normals and mutant mice, respectively; derived from data in Table I). In an earlier study we showed that $1,25(\mathrm{OH})_{2} \mathrm{D}_{3}$ treatment of $H y p$ mice also failed to correct the brush border membrane phosphate transport defect, although it improved phosphate homeostasis in Hyp mice by stimulating intestinal phosphate absorption (28). Taken together, the data suggest that the primary defect in $H y p$ mice is a disorder in phosphate homeostasis, which most likely involves the renal brush border membrane phosphate transporter or a regulator thereof.

It is of interest that the low-Pi diet elicits a significant rise in serum calcium and a substantial hypercalciuric response in both genotypes, yet only the normal mice respond to phosphate deprivation with increased serum levels of $1,25(\mathrm{OH})_{2} \mathrm{D}$. These data suggest that the calcemic and calciuric responses to phosphate deprivation are not dependent on the elevation in serum $1,25(\mathrm{OH})_{2} \mathrm{D}$ as was previously suggested (29). Although the calciuric response may be ascribed to a fall in the circulating concentration of PTH, evidenced by the diet-induced fall in urinary cAMP, it is difficult to explain the increase in serum calcium by the same mechanism.

The present study provides a further rationale for the efficacy of combined therapy with oral phosphate and $1,25(\mathrm{OH})_{2} \mathrm{D}_{3}$ in the treatment of patients with $\mathrm{X}$-linked hypophosphatemia $(2,4,30)$. Phosphate supplementation, which is necessary to stimulate bone mineralization in these patients, may also play an important role in the maintenance of the steady-state serum concentration of $1,25(\mathrm{OH})_{2} \mathrm{D}$ by reducing its rate of degradation and promoting its rate of synthesis by the kidney.

\section{Acknowledgments}

We thank Georgia Kalavritinos, John Lee, and Valarie Byford for excellent technical assistance, Moira Mills for the urine cAMP assay, Antonio Ciampi and Danielle Boutin for statistical analysis, and Lynne Prevost for preparation of the manuscript.

This work was supported by the MRC Genetics Group grant (to H. S. Tenenhouse) and by grants MA-9475 and DG-305 from the Medical Research Council of Canada (to G. Jones).

This is publication no. 90-013 from the McGill University-Montreal Children's Hospital Research Institute.

\section{References}

1. Eicher, E. M., J. L. Southard, C. R. Scriver, and F. H. Glorieux. 1976. Hypophosphatemia: mouse model for human familial hypophosphatemic (vitamin D-resistant) rickets. Proc. Natl. Acad. Sci. USA. 73:4667-4671.

2. Rasmussen, H., and H. S. Tenenhouse. 1989. Hypophosphatemias. In The Metabolic Basis of Inherited Disease. C. R. Scriver, A. L. Beaudet, W. S. Sly, and D. Valle, editors. 6th ed. McGraw-Hill Inc., New York. 2581-2601.

3. Meyer, R. A., Jr., R. W. Gray, and M. H. Meyer. 1980. Abnormal vitamin $D$ metabolism in the X-linked hypophosphatemic mouse. Endocrinology. 107:1577-1581.

4. Glorieux, F. H., P. J. Marie, J. M. Pettifor, and E. E. Delvin. 1980. Bone response to phosphate salts, ergocalciferol, and calcitriol in hypophosphatemic vitamin D-resistant rickets. N. Engl. J. Med. 303:1023-1031.

5. Tenenhouse, H. S. 1983. Abnormal renal mitochondrial 25-hydroxyvitamin $\mathrm{D}_{3}-1$-hydroxylase activity in the vitamin $\mathrm{D}$ and calcium deficient X-linked Hyp mouse. Endocrinology. 113:816-818.

6. Tenenhouse, H. S. 1984. Metabolism of 25-hydroxyvitamin $D_{3}$ in renal slices from the X-linked hypophosphatemic ( $H y p)$ mouse: abnormal response to fall in serum calcium. Cell Calcium. 5:43-55.

7. Tenenhouse, H. S. 1984. Investigation of the mechanism for abnormal renal 25 -hydroxyvitamin $\mathrm{D}_{3}$-1-hydroxylase activity in the X-linked Hyp mouse. Endocrinology. 115:634-639.

8. Nesbitt, T., M. K. Drezner, and B. Lobaugh. 1986. Abnormal parathyroid hormone stimulation of 25-hydroxyvitamin D-1 $\alpha$-hydroxylase activity in the hypophosphatemic mouse. J. Clin. Invest. 77:181-187.

9. Drezner, M. K. 1984. The role of abnormal vitamin D metabolism in X-linked hypophosphatemic rickets and osteomalacia. $A d v$. Exp. Med. Biol. 178:399-404.

10. Yamaoka, K., Y. Seino, K. Satomura, Y. Tanaka, H. Yabuuchi, and M. R. Haussler. 1986. Abnormal relationship between serum phosphate concentration and renal 25-hydroxycholecalciferol-1alpha-hydroxylase activity in X-linked hypophosphatemic mice. Miner. Electrolyte Metab. 12:194-198.

11. Tenenhouse, H. S., A. Yip, and G. Jones. 1988. Increased renal catabolism of 1,25-dihydroxyvitamin $\mathrm{D}_{3}$ in murine $\mathrm{X}$-linked hypophosphatemic rickets. J. Clin. Invest. 81:461-465.

12. Jones, G., A. Yip, and H. S. Tenenhouse. 1987. Side-chain oxidation of vitamin $D_{3}$ in mouse kidney mitochondria: effect of the Hyp mutation and 1,25-dihydroxyvitamin $\mathrm{D}_{3}$ treatment. Biochem. Cell Biol. 65:853-859.

13. Fraser, D. 1980. Regulation of the metabolism of vitamin D. Physiol. Rev. 60:551-613.

14. Tenenhouse, H. S., and G. Jones. 1987. Effect of the X-linked Hyp mutation and vitamin D status on induction of renal 25-hydroxyvitamin $\mathrm{D}_{3}$-24-hydroxylase. Endocrinology. 120:609-616. 
15. Vieth, R., and D. Fraser. 1979. Kinetic behaviour of 25-hydroxyvitamin D-1-hydroxylase and -24-hydroxylase in rat kidney mitochondria. J. Biol. Chem. 254:12455-12460.

16. Bligh, E. G., and W. J. Dyer. 1959. A rapid method for total lipid extraction and purification. Can. J. Biochem. 37:911-917.

17. Jones, G. 1983. Chromatographic separation of 24(R),25-dihydroxyvitamin $\mathrm{D}_{3}$ and 25-hydroxyvitamin $\mathrm{D}_{3}$-26,23-lactone using a cyano-bonded phase packing. J. Chromatogr. 276:69-75.

18. Jones, G. 1986. Elucidation of a new pathway of 25-hydroxyvitamin $\mathrm{D}_{3}$ metabolism. Methods Enzymol. 123:141-154.

19. Tanaka, Y., and H. F. DeLuca. 1973. The control of 25-hydroxyvitamin D metabolism by inorganic phosphorus. Arch. Biochem. Biophys. 154:566-574.

20. Baxter, L. A., and H. F. DeLuca. 1976. Stimulation of 25-hydroxyvitamin $\mathrm{D}_{3}-1 \alpha$-hydroxylase by phosphate depletion. J. Biol. Chem. 251:3158-3161.

21. Gray, R. W., and J. L. Napoli. 1983. Dietary phosphate deprivation increases 1,25 -dihydroxyvitamin $D_{3}$ synthesis in rat kidney in vitro. J. Biol. Chem. 258:1152-1155.

22. Cunningham, J., H. Gomes, Y. Seino, and L. R. Chase. 1983. Abnormal 24-hydroxylation of 25-hydroxyvitamin $\mathrm{D}$ in the $\mathrm{X}$-linked hypophosphatemic mouse. Endocrinology. 112:633-638.

23. Portale, A. A., B. P. Halloran, M. M. Murphy, and R. C. Morris. 1986. Oral intake of phosphorus can determine the serum concentration of 1,25-dihydroxyvitamin $\mathrm{D}$ by determining its production rate in humans. J. Clin. Invest. 77:7-12.

24. Seino, Y., K. Yamaoka, M. Ishida, Y. Tanaka, H. Kurose, H.
Yabuuchi, Y. Tohira, M. Fukushima, and Y. Nishii. 1982. Plasma clearance for high doses of exogenous 1,25-dihydroxy[23,24(n)- $\left.{ }^{3} \mathrm{H}\right]$ cholecalciferol in $\mathrm{X}$-linked hypophosphatemic mice. Biomed. Res. 3:683-687.

25. Tenenhouse, H. S., and M. Gharhemani. 1988. Intestinal metabolism of 25-hydroxyvitamin $\mathrm{D}_{3}$ : effect of the X-linked Hyp mutation and 1,25-dihydroxyvitamin $\mathrm{D}_{3}$ treatment. In Vitamin D, Molecular, Cellular and Clinical Endocrinology. A. W. Norman, K. Schaefer, H.-G. Grigoleit, and D. V. Herrath, editors. Walter de Gruyter \& Co., New York. 116-117.

26. Delvin, E. E., P. Richard, B. Ecarot-Charrier, and F. H. Glorieux. 1988. Calcitriol receptors in cultured Hyp mouse osteoblasts. $J$. Bone Miner. Res. 3:S133. (Abstr.)

27. Tenenhouse, H. S., D. K. Fast, C. R. Scriver, and M. Koltay. 1981. Intestinal transport of phosphate anion is not impaired in the Hyp (Hypophosphatemic) mouse. Biochem. Biophys. Res. Commun. 100:537-543.

28. Tenenhouse, H. S., and Scriver, C. R. 1981. Effect of 1,25-dihydroxyvitamin $\mathrm{D}_{3}$ on phosphate homeostasis in the X-linked hypophosphatemic (Hyp) mouse. Endocrinology. 109:658-660.

29. Gray, R. W. 1981. Control of plasma $1,25-(\mathrm{OH})_{2}$-vitamin D concentrations by calcium and phosphorus in the rat: effects of hypophysectomy. Calcif. Tissue Int. 33:485-488.

30. Harrell, R. M., K. W. Lyles, J. M. Harrelson, N. E. Friedman, and M. K. Drezner. 1985. Healing of bone disease in X-linked hypophosphatemic rickets/osteomalacia. Induction and maintenance with phosphorus and calcitriol. J. Clin. Invest. 75:1858-1868. 